Research Journal of Environmental and Earth Sciences 12(2): 29-37, 2020

DOI: $10.19026 /$ rjees. 12.6049

ISSN: 2041-0484; e-ISSN: 2041-0492

(C) 2020 Maxwell Scientific Publication Corp.

Submitted: March 2, 2020

Accepted: May 8, 2020

Published: August 25, 2020

\title{
Research Article Composition of Clay Filters for Water Treatment in Akutuase: A Rural Community in Western Region, Ghana
}

\author{
${ }^{1}$ Kofi Asante-Kyei, ${ }^{2}$ Anthony Adjorlolo-Gasokpoh and ${ }^{3}$ Emily Otoo-Quayson \\ ${ }^{1}$ Department of Ceramic Technology, \\ ${ }^{2}$ Department of Industrial and Health Sciences, Takoradi Technical University, \\ P.O. Box 256, Takoradi, Ghana \\ ${ }^{3}$ Department of Civil Engineering, Faculty of Engineering, \\ KNUST-Kumasi, Ghana
}

\begin{abstract}
The purpose of this study was to compose clay filters made from local materials for the efficiency of water impurities removal for rural households. Clay filters were manufactured by using local materials: Akutuase clay, sawdust gathered from a sawmill unit, and rice husks from rice farmers at Akutuase. These materials were ground and sieved to obtain finer particle sizes, weighed, and proportionally wet mixed. Pots were then made, dried, and fired in a kiln at temperatures of 850,900 , and $950^{\circ} \mathrm{C}$, respectively. A silver coating was artificially applied to the fired filters using $0.1 \mathrm{mg} / \mathrm{L}$ of silver solution. Raw water fetched from a stream in Akutuase was filtered using the pots. The filtered water was tested for microbial removal efficiency of the composed clay filters at Ghana Water Company, Takoradi. It was revealed that compositions $\mathrm{C}_{3} 80$ and $\mathrm{C}_{4} 80$ made up of $80 \%$ clay, $15 \%$ rice husks and $5 \%$ sawdust that were fired at 900 and $950^{\circ} \mathrm{C}$ respectively, became successful and suitable for water filtration. However, it was highly successful when the temperature was $950^{\circ} \mathrm{C}$ due to comparatively the greater quantity of water that $\mathrm{C}_{4} 80$ was able to filter. The results suggested that the silver-impregnated ceramic filter constructed was highly efficient and effective in the removal of bacteria. It had been recommended among others that, as a measure to prevent water-borne diseases in Akuatuase, institutions should invest in setting up small scale ceramic industry in the community for mass-production of clay filters to serve the rural folks. Further studies should be extended to analyze the removal of other pathogens including viruses and protozoa for different water-quality conditions. Additionally, the long-term field performance of locally produced filters and their effects on human health must be investigated.
\end{abstract}

Keywords: Clay, filters, local materials, rural, treatment, water

\section{INTRODUCTION}

Untreated surface water or groundwater is often contaminated with pathogens of faecal sources. Faecal origin comes about as a result of human activities in the catchment area of the surface water. Storage and transport of the water are some of its contamination (Clasen et al., 2004). According to World Health Organization (WHO) sponsored review on improved water supply, it was concluded that simple, socially acceptable and low-cost interventions at the household and community level have the potential to significantly improve the microbial quality of household water and reduce the risk of diarrhea, dehydration, other waterrelated diseases and even death particularly among children (Sobsey, 2002). In Ghana, there is an abundance of clay as a natural resource. Geologically, a study has revealed that clay is found in almost every part of the country (Danquah, 2005). Akutuase, a rural community in the Western Region is endowed with clay deposits and the main farming activity is all year round rice farming. After rice harvesting, the rice husk that is a waste product is openly burnt, thereby polluting the environment. Clay is defined as an earth that forms a sticky mass when mixed with water; when wet, this mass is readily moldable, but if dried it becomes hard and retains its shape. Additionally, if heated to redness, it becomes still harder and is no longer susceptible to the action of water (Speight and Toki, 1999). Such a material lends itself to the making of wares of all shapes.

Statement of the problem: In Ghana, despite the state effort to provide good drinking water for its citizenry,

Corresponding Author: Kofi Asante-Kyei, Department of Ceramic Technology, Takoradi Technical University, P.O. Box 256, Takoradi, Ghana

This work is licensed under a Creative Commons Attribution 4.0 International License (URL: http://creativecommons.org/licenses/by/4.0/). 
most of the rural folks still depend on rivers, streams and other water bodies as sources of drinking water for domestic and other uses. Again, there are material resources that could be exploited for other useful needs in the society instead of burning them to pollute the environment. Among such materials are sawdust, rice husk, maize husk and charcoals which could be recycled. Recycling appears to point to a way of solving the problem of pollution, which seems to be global and needs a practical and realistic approach. It is against this backdrop that this study seeks to recycle sawdust and rice husks to compose clay filters for removal of water impurities to make water safe for drinking, especially among the indigenes of Akutuase, a rural community in Western Region.

Objective of the study: The purpose of this study is to compose prototype clay filters by using clay, sawdust and rice husks all obtained from Akutuase for determining the efficiency of water impurities removal for rural households.

Research question: Can composed clay filters remove water impurities and make it drinkable?

\section{Importance of the study:}

- Findings from the study would be useful to the people of Akutuase for accessing safe water in their areas.

- It will also be useful to a Community and Water Sanitation Project (CWSP); an agency in charge of water treatment for rural areas in Ghana.

Delimitation: The study was delimited to the use of Akutuase clay, sawdust and rice husks for the composition of clay filters.

Review of water, unsafe water and ceramic filters: According to Annan (2016), over 70\% of an earth surface is known to be covered with water. The essential issue is that there is a proportion of fresh water available for safe drinking. Surface waters are often contaminated and required specialized filters to make them safe for drinking. Again, surface water continues to dry up mainly due to the adverse climatic conditions. The available ones are also often contaminated with either chemicals or microbial agents that are detrimental to the health of an individual and therefore not safe to drink (Annan, 2016). Water is unsafe when it contains worms, germs, or toxic chemicals. Toxic pollution in water is as a result of agriculture, mining, oil drilling and many other industries chemical wastes dump into water sources. This makes the water unsafe to drink or to use for preparing food, for bathing, or irrigation (Conant and Fadem, 2012). Although most microorganisms in a water are harmless, some can cause problems. Bacteria from human or livestock waste can cause serious health problems such as

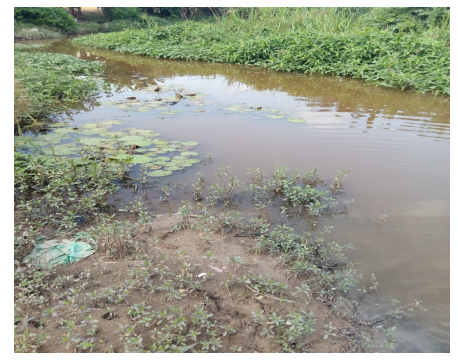

Fig. 1: A stream serving as a source of water in Akutuase

typhoid fever, hepatitis and dysentery. Current data shows that about 884 million people worldwide are still without good drinking water (WHO, 2010). This is even more pronounced in the Sub-Sahara Africa where about $34 \%$ of this water-deprived people are currently living. Again, the World Bank predictions of 2003, show that $25 \%$ of Sub-Sahara Africa will not be having access to portable resources in 2015 and beyond (Chung et al., 2013; Hillie et al., 2009), hence measures should be put in place to provide water in these areas.

Annan (2016) mentions that water from any source such as river, stream, borehole and several others may have some dissolved minerals, microbiological contaminants and suspended particles. The amount present in the final analysis and whether it is suitable for its intended purpose is essential. Microbial activity such as bacteria, viruses, chemical contaminants such as iron, fluoride, magnesium, nitrate, arsenic, sulphates, $\mathrm{pH}$ of water, among others, are issues found in drinking water that provides health risks. From Annan's (2016) assertions, the Akutuase stream which serves as drinking water has high potential health risk as seen in Fig. 1.

According to Rob et al. (2003), one of the methods of water purification is the use of ceramic filters. These filters may be produced with different materials and in various forms; however, the most common ceramic filters in the world are diatomaceous filters, which are made in vase forms, plates and candles. These filters have become conventional in some parts of the world such as India and Nepal (Mintz et al., 1995; NRC, 1997). Ceramic filtration is the use of porous ceramic (fired clay) to filter microbes or other contaminants from portable drinking water. Pore size can be made small enough depending on the composition to remove virtually all bacteria and protozoa, 0.2 ųm, in the range referred to as microfiltration (Sobsey, 2002). In most cases, ceramic water filters are mixtures of clays, sawdust and water molded and fired. Sawdust material burns out at temperature around $400-500^{\circ} \mathrm{C}$, creating pores. The effectiveness of the ceramic water filter in the production of safe drinking water has been successful in research studies. This study tends to explore other materials to augment the use of sawdust in composing ceramic water filters. 


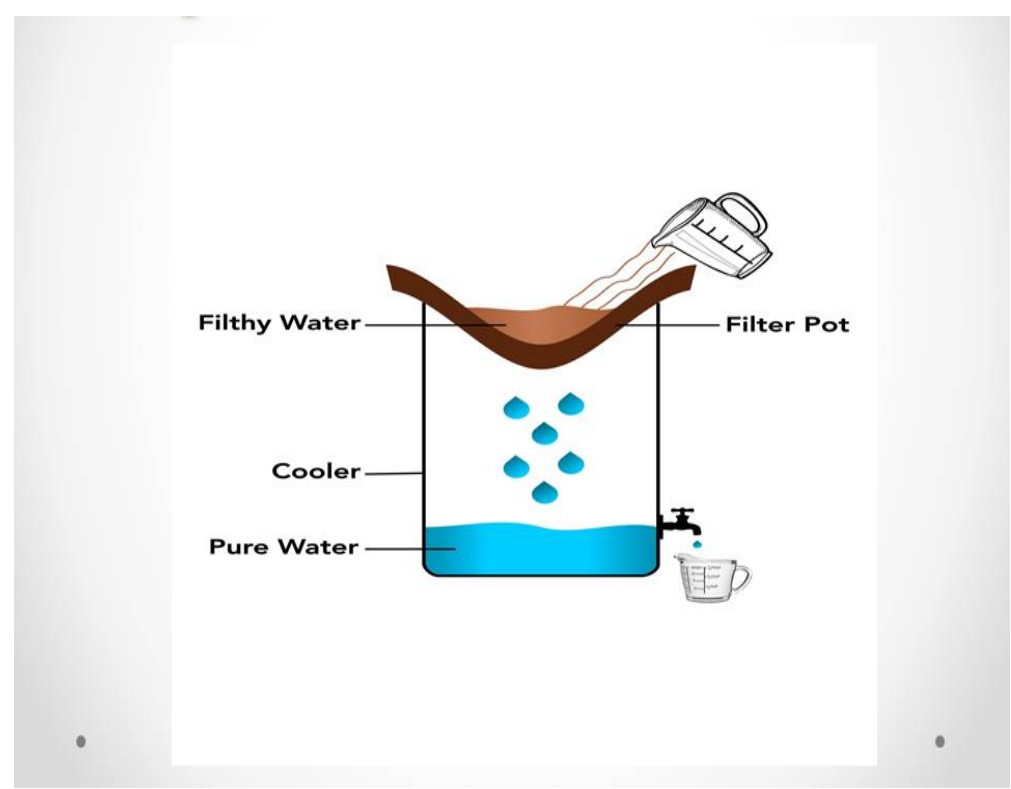

Fig. 2: Prototype clay filter

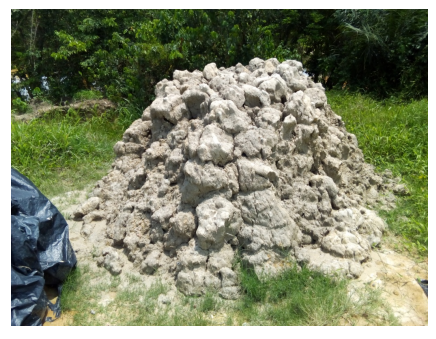

Fig. 3: Clay mined near a stream in Akutuase

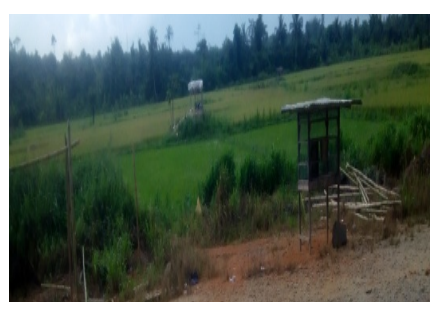

Fig. 4: Rice farm in Akutuase

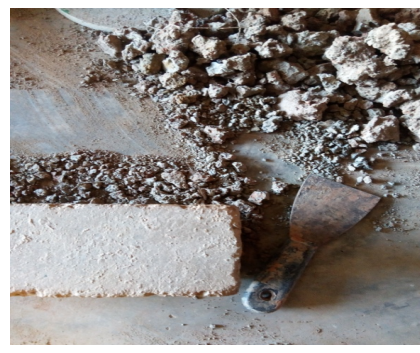

Fig. 5: Processed clay from Akutuase

\section{MATERIALS AND METHODS}

Preliminary design: A prototype of the clay filter was designed to suit the purpose of the study. It comprised filter pot to be composed with clay bodies that would hold filthy water, plastic container (cooler) to contain filtered water and a tap to flow pure water as demonstrated in Fig. 2.

Materials: The raw materials needed were picked from various locations within Akutuase. A sample of clay mined from the stream of Akuatuase shown in Fig. 3 was used in the fabrication of the clay water filters. The clay was mixed with powdered sawdust obtained from a sawmill unit and rice husks from the rice farming in Akutase as captured in Fig. 4. The materials were crushed and processed into dry powdered form. The clay constituted the base material in the clay body while saw dust and rice husks were used as the burnout materials to create more holes in the fired clay and also to possibly introduce activated carbon into the filter to serve as means for the absorption and removal of traces and heavy metals like sulphate and lead from water (Erhuanga et al., 2014).

Processing of materials: Initial test was carried out to determine the plasticity and porosity of the Akutuase clay and it was successful. The clay, sawdust and rice husk were crushed and sieved through $1 \mathrm{~mm}$ pores to attain finer particle sizes as seen in Fig. 5 to 7 respectively.

Method of composing clay bodies for clay pots: The sieved clay powder and combustible materials were taken in the required proportion and manually mixed dry, then wetted by adding water, then kneaded and rolled to get a uniformed mixture as highlighted in Fig. 8. 


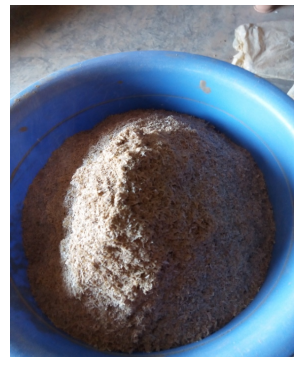

Fig. 6: Processed sawdust from Akutuase

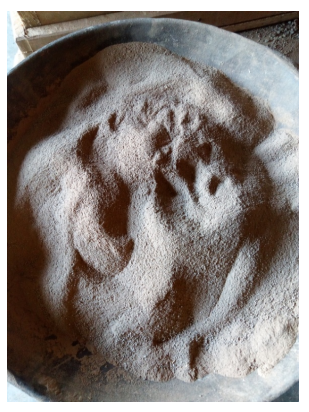

Fig. 7: Processed rice husk from Akutuase

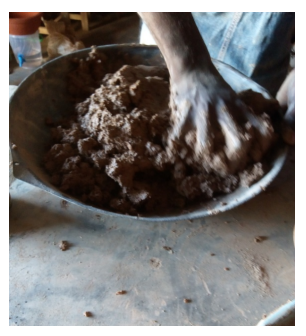

Fig. 8: Hand mixing of weighed materials

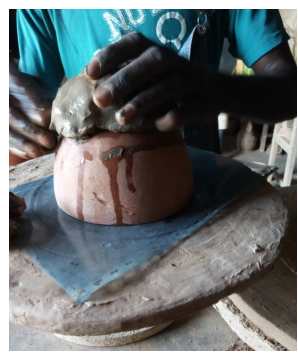

Fig. 9: Raw mold being used for pressing

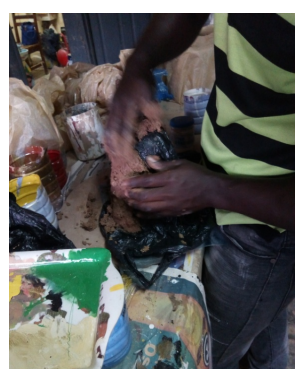

Fig. 10: Mold covered with polythene to press
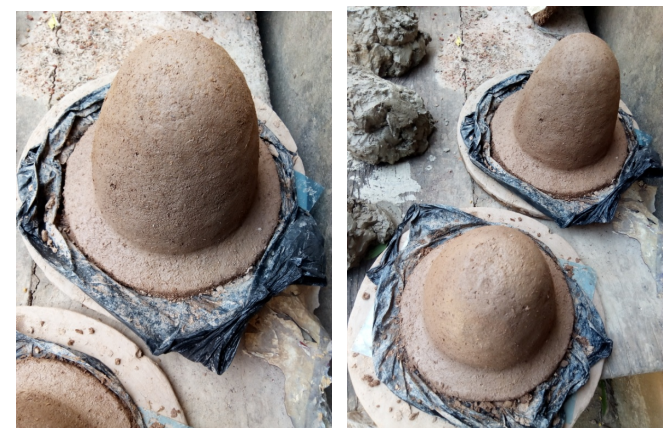

Fig. 11: Samples of pressed clay filters

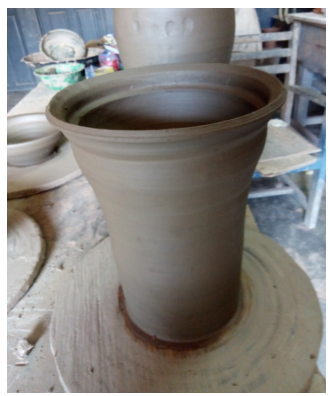

Fig. 12: Sample of smooth pressed clay filter ready for drying

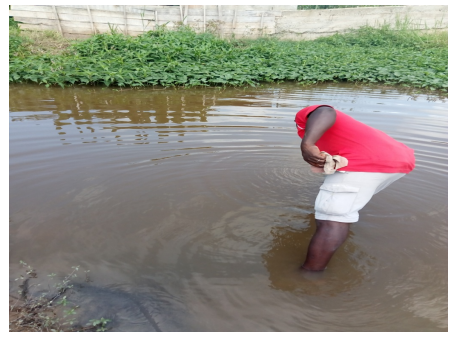

Fig. 13: Fetching of water from a stream in Akutuase

Clay mixtures were molded into shapes of a flower pot on a cast moulds. One mold was not covered as exhibited in Fig. 9 while the other was covered with polythene as seen in Fig. 10. Initial tests proved that the cast mould with polythene could cast successfully as compared with the raw mold.

The mold with polythene was therefore used to press the clay filters. The process was repeated until several clay filters were pressed as found in Fig. 11.

The pressed clay filters were allowed to dry in an open-air at an average high temperature of $27^{\circ} \mathrm{C}$, average low temperature of $20^{\circ} \mathrm{C}$ and average humidity of $58 \%$ in a dry place for 2 weeks. The purpose of this atmosphere was to ensure uniform drying and also to prevent warping and cracking of the clay filters as seen in Fig. 12.

The pressed dry clay filters samples were packed into a gas kiln and fired at 850,900 and $950^{\circ} \mathrm{C}$, respectively. Four samples were selected to undertake the experiment as shown in Table 1. 
Res. J. Environ. Earth Sci., 12(2): 29-37, 2020

Table 1: Composition of clay, rice husks, sawdust and heating temperature

\begin{tabular}{lllll}
\hline Filter number & Clay weight $(\%)$ & Rice husks weight $(\%)$ & Sawdust weight $(\%)$ & Heating temperature $\left({ }^{\circ} \mathrm{C}\right)$ \\
\hline $\mathrm{C}_{1} 70$ & 70 & 25 & 5 & 850 \\
$\mathrm{C}_{2} 75$ & 75 & 20 & 5 & 900 \\
$\mathrm{C}_{3} 80$ & 80 & 15 & 5 & 900 \\
$\mathrm{C}_{4} 80$ & 80 & 15 & 5 & 950 \\
\hline
\end{tabular}

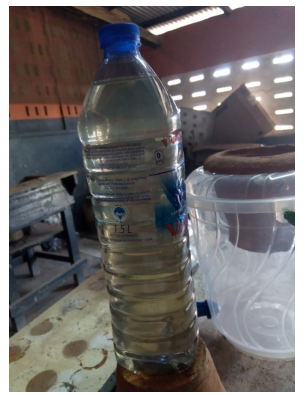

Fig. 14: Contaminated water

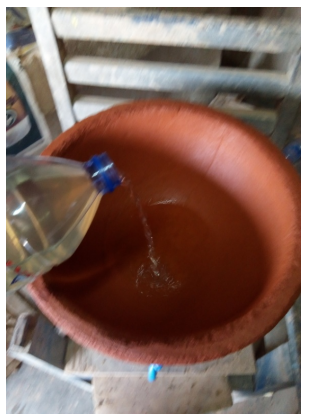

Fig. 15: Pouring of contaminated water into a filter

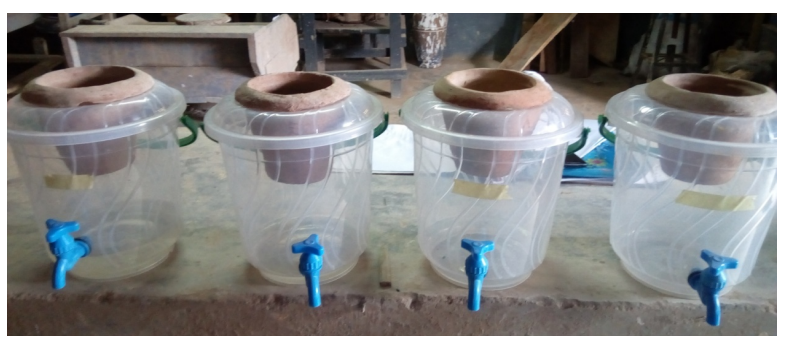

Fig. 16: Levels of filtered water after $1 \mathrm{~h}$ in fired clay filters $\left(\mathrm{C}_{1}\right.$ to $\left.\mathrm{C}_{4}\right)$

Water samples were fetched from a stream in Akutuase (Fig. 13) by employing purposeful sampling technique. The contaminated water was stored in cleaned sterile plastic containers (Fig. 14).

After firing, the cylindrical ceramic filters were artificially coated with $10 \mathrm{~mL}$ of $0.1 \mathrm{mg} / \mathrm{L}$ of silver solution on the inner walls of each of the filters and left to stand for $30 \mathrm{~min}$ before the contaminated water was poured as demonstrated in Fig. 15.

The flow rate of water was conducted by measuring the quantity of water that filtrated after 60 min. The levels of quantity of water that was able to filtrate the composed fired clay filters were determined and observed as shown in Fig. 16.

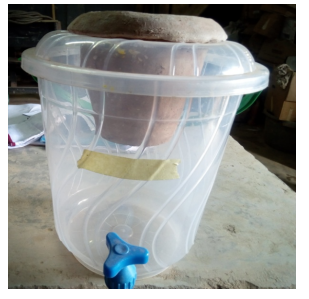

Fig. 17: Filtration of composition $\mathrm{C}_{1} 70$ in a container

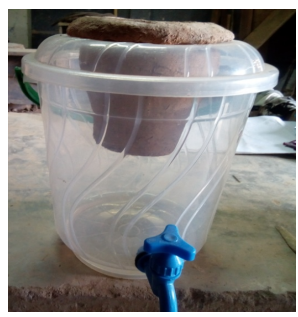

Fig. 18: Filtration of composition $\mathrm{C}_{2} 75$ in a container

\section{RESULTS AND DISCUSSION}

The filtration process was conducted to determine the quantity of filtered water in the various composed clay filters. The following results were obtained.

Composition $\left(\mathrm{C}_{170} \mathbf{7 0}\right.$ made up of $70 \%$ clay, $25 \%$ rice husks and 5\% sawdust fired at a temperature of $850{ }^{\circ} \mathrm{C}$ : It was realised that the rate of water that flowed through composition $\mathrm{C}_{1} 70$ after 60 min was almost empty as seen in Fig. 17. This could be due to low porosity of the composed filter emanated from the higher composition of burnt-out material in the composition and relatively low temperature of $850^{\circ} \mathrm{C}$.

Composition $\left(\mathrm{C}_{2} 75\right)$ made up of $75 \%$ clay, $20 \%$ rice husks and $5 \%$ sawdust fired at a temperature of 900 ${ }^{\circ} \mathbf{C}$ : It was revealed that the rate of water that flowed through composition $\mathrm{C}_{2} 75$ after 60 min was least filtered or had the smallest quantity of water passing through the composed filter as indicated in Fig. 18. The reason assigned could be due to relatively increased in temperature of $900^{\circ} \mathrm{C}$ as compared with the composition $\mathrm{C}_{1} 70$ and again relatively low porosity of the composed filter resulted from the comparatively high composition of burnt-out material in the composition.

Composition $\left(\mathrm{C}_{3} 80\right)$ consisted of $\mathbf{8 0 \%}$ clay, $\mathbf{1 5 \%}$ rice husks and $5 \%$ sawdust fired at a temperature of $900^{\circ} \mathrm{C}$ : It came to light that the rate of 
Res. J. Environ. Earth Sci., 12(2): 29-37, 2020

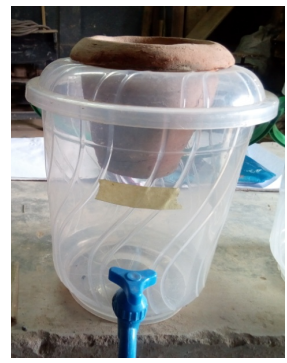

Fig. 19: Filtration of composition $\mathrm{C}_{3} 80$ in a container

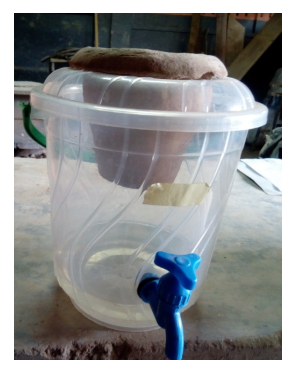

Fig. 20: Filtration of composition $\mathrm{C}_{4} 80$ in a container

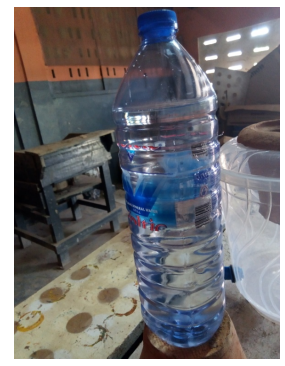

Fig. 21: Filtered water of $\mathrm{C}_{4} 80$ in a plastic bottle ready for test

water that flowed through composition $\mathrm{C}_{3} 80$ after 60 min was more filtered or had a higher quantity of water passing through the composed filter as seen in Fig. 19 compared with the composion $\mathrm{C}_{2} 75$. It could be attributed to relatively increased in percentage of clay as compared with the composition $\mathrm{C}_{2} 75$ and again relatively high porosity of the composed filter resulted from the comparatively low composition of burnt-out materials ( $15 \%$ rice husks) in the composition.

Composition $\left(\mathrm{C}_{4} 80\right)$ consisting of $80 \%$ clay, $15 \%$ rice husks and $5 \%$ sawdust fired at a temperature of $950^{\circ} \mathrm{C}$ : It was demonstrated that the rate of water that flowed through composition $\mathrm{C}_{4} 80$ after 60 min was highly filtered or had the highest quantity of water passing through the composed filter as captured in Fig. 20 compared with the composition $\mathrm{C}_{3} 80$. It could be associated to relatively increased in temperature as compared with the composition $\mathrm{C}_{3} 80$ and again relatively highest porosity due to comparatively high maturing temperature $\left(950^{\circ} \mathrm{C}\right)$ of the composed filter resulted from the comparatively low composition of burnt-out materials $(15 \%$ rice husks $)$ in the composition.

The water that passed through the filter pot $\left(\mathrm{C}_{4} 80\right)$ was collected and poured into a plastic bottle as seen in Fig. 21 for water analysis at Ghana Water Company, Takoradi. The purpose of the water analysis was to find out if the clay filter could remove bacterial and other particles from the filtered water.

Porosity of the clay filters form the basis for removal of particles in micro-size level. The pore sizes of the fired clay water filters determine the ability to remove particles and pathogens from water (Bielefeldt et al., 2010). As a result of that porosity test was conducted on composition $\mathrm{C}_{4} 80$ to ascertain its flow rate. Zereffa and Bekalo (2017) hold the view that the flow rates of ceramic filters increase with the increase of the content of combustible material. However, composition $\mathrm{C}_{4} 80$ that had relatively low combustible materials but high clay content $(80 \%)$ and fired at a maturing temperature of $950^{\circ} \mathrm{C}$ had a greater quantity of filtered water. Clasen et al. (2007) mentions that ceramic water filters with relatively low porosity have good efficiency in removing microbial pollution from contaminated water sources. It could be deduced from Fig. 16 (all containers) that composition $\mathrm{C}_{4} 80$ filter relatively had a large number of pores per surface area and thus had a greater flow rate, followed by $\mathrm{C}_{3} 80$ and $\mathrm{C}_{2} 75$; whereas $\mathrm{C}_{1} 70$ filter might have small pore number per surface area resulted in little or no flow rate.

The process of testing for microbial removal efficiency of the composed clay filter $\mathrm{C}_{4} 80$ and sample of filthy water were carried out at Ghana Water Company, Takoradi. From Fig. 21, the colour of the filtered water confirmed Naddafi et al. (2005) assertion that clay filters have efficiency in reducing significantly the colour of contaminated water (above 60\%) and also have high potential in turbidity removal (above $90 \%)$.

The test analysis result produced before the filtration was carried out has been highlighted in Fig. 22. Afterwards, the test analysis results produced after the filtration was also conducted as shown in Fig. 23.

The analysis consisted of testing for bacterial counts. Sample of raw water (before) and filtered water $\mathrm{C}_{4} 80$ (after) were tested for total coliform, faecal coliform, E. coli and total heterotrophic bacteria as shown in Table 2.

The analyses performed show that the Silverimpregnated Ceramic Filter (CFS) constructed from natural materials can effectively reduce the number of bacteria in water (Table 2). Again, the number of faecal coliform and E. Coli were removed completely from 52 and $46 \mathrm{cfu} / \mathrm{mL}$ respectively. However, total coliforms which were Too Numerous to Count (TNTC) before 
Res. J. Environ. Earth Sci., 12(2): 29-37, 2020

\section{Test result produced before filtration}

\begin{tabular}{|c|c|c|c|c|c|c|}
\hline \multicolumn{4}{|c|}{$\begin{array}{l}\text { Received from: Ms. Emily Otoo-Quayson (IGEM) } \\
\text { Source: River } \\
\text { Sample Label: Sample A(Before Filtration) } \\
\text { Address: P. O .Box MC 0869, Takoradi. }\end{array}$} & \multicolumn{3}{|c|}{$\begin{array}{l}\text { Date of Sampling: } 01 / 08 / 2018 \\
\text { Date received: } 01 / 08 / 2018 \\
\text { Date analysis commenced: } 01 / 08 / 2018 \\
\text { Ref. No: }\end{array}$} \\
\hline NO & PARAMETERS. & UNIT & Gui & $\begin{array}{l}\text { WHO } \\
\text { IDELINE } \\
\text { ALUES }\end{array}$ & $\begin{array}{c}\text { GSA } \\
\text { STANDARDS }\end{array}$ & $\begin{array}{c}\text { SAMPLE } \\
\text { MEASURED } \\
\text { VALUE }\end{array}$ \\
\hline 1 & Total Coliforms & $(\mathrm{cfu} / \mathrm{ml})$ & & 0 & 0 & TNTC \\
\hline 2 & Faecal Coliforms & $(\mathrm{cfu} / \mathrm{ml})$ & & 0 & 0 & 52 \\
\hline 3 & E. Coli & $(\mathrm{cfu} / \mathrm{ml})$ & & 0 & 0 & 46 \\
\hline 4 & Total Heterotrophic bacteria & (count $/ \mathrm{ml}$ ) & & - & 500 & 148 \\
\hline
\end{tabular}

TC $=$ Too Numerous To Count

Remarks: Coliforms counts are unacceptable.

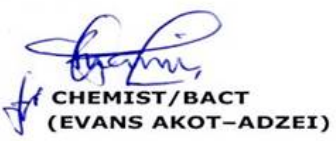

REG. WATER QUALITY MANAGER

GHANA WATER COMPANY LTD.

TAKORADI

Fig. 22: Test report produced before filtration from Ghana water company, Takoradi

\section{Test result produced after filtration}

\begin{tabular}{|c|c|c|c|c|c|c|}
\hline \multicolumn{4}{|c|}{$\begin{array}{l}\text { Received from: Ms. Emily Otoo-Quayson (IGEM) } \\
\text { Source: River } \\
\text { Sample Label: Sample B(After Filtration) } \\
\text { Address: P . O Box MC 0869, Takoradi. }\end{array}$} & \multicolumn{3}{|c|}{$\begin{array}{l}\text { Date of Sampling: } 01 / 08 / 2018 \\
\text { Date received: } 01 / 08 / 2018 \\
\text { Date analysis commenced: } 01 / 08 / 2018 \\
\text { Ref. No: }\end{array}$} \\
\hline NO & PARAMETERS. & UNIT & & $\begin{array}{l}\text { VHO } \\
\text { DELINE } \\
\text { LUES }\end{array}$ & $\begin{array}{l}\text { GSA } \\
\text { STANDARDS }\end{array}$ & $\begin{array}{l}\text { SAMPLE } \\
\text { MEASURED } \\
\text { VALUE }\end{array}$ \\
\hline 1 & Total Coliforms & $(\mathrm{cfu} / \mathrm{ml})$ & & 0 & 0 & 7 \\
\hline 2 & Faecal Coliforms & $(\mathrm{cfu} / \mathrm{ml})$ & & o & 0 & 0 \\
\hline 3 & E. Coli & $(\mathrm{cfu} / \mathrm{ml})$ & & 0 & 0 & 0 \\
\hline 4 & Total Heterotrophic bacteria & (count/ml) & & - & 500 & 8 \\
\hline \multicolumn{7}{|c|}{ Remarks: Total Coliforms count is higher than the guideline value. } \\
\hline \multicolumn{7}{|c|}{$f \begin{array}{l}\text { CHEMIST/BACT } \\
f \text { (EVANS AKOT-ADZEI) }\end{array}$} \\
\hline \multicolumn{7}{|c|}{$\begin{array}{l}\text { REG. WATER QUALITY MANAGER } \\
\text { GHANA WATER COMPANY LTD. } \\
\text { TAKORADI }\end{array}$} \\
\hline
\end{tabular}

Fig. 23: Test report after filtration $\left(\mathrm{C}_{4} 80\right)$ from Ghana water company, Takoradi 
Res. J. Environ. Earth Sci., 12(2): 29-37, 2020

Table 2: Test results produced before and after filtration from Ghana water company, Takoradi

\begin{tabular}{|c|c|c|c|c|c|c|c|}
\hline \multirow[b]{2}{*}{ Parameters } & \multirow[b]{2}{*}{ Unit } & \multicolumn{2}{|c|}{ WHO guideline values } & \multicolumn{2}{|c|}{ GSA standards } & \multicolumn{2}{|c|}{ Sample measured values } \\
\hline & & Before & After & Before & After & Before & After \\
\hline Total coliforms & $(\mathrm{cfu} / \mathrm{mL})$ & 0 & 0 & 0 & 0 & TNTC & 7 \\
\hline Faecal coliforms & $(\mathrm{cfu} / \mathrm{mL})$ & 0 & 0 & 0 & 0 & 52 & 0 \\
\hline E. coli & $(\mathrm{cfu} / \mathrm{mL})$ & 0 & 0 & 0 & 0 & 46 & 0 \\
\hline Total heterotrophic bacteria & (count $/ \mathrm{mL})$ & - & - & 500 & 500 & 148 & 8 \\
\hline
\end{tabular}

TNTC: Too numerous to count; WHO: World health organisation; GSA: Ghana standard authority

filtration was removed to an amount of $7 \mathrm{cfu} / \mathrm{mL}$. According to WHO guidelines for the total coliforms, faecal coliform and E. coli in drinking water should be no amount of these bacteria (that is, zero number of these bacteria). The results suggest that the silverimpregnated ceramic filter constructed was highly efficient and effective in the removal of bacteria. Total Heterotrophic Bacteria count before filtration was 148 count $/ \mathrm{mL}$ while after filtration $\mathrm{C}_{4} 80$ recorded 8 count $/ \mathrm{mL}$ with GSA recommendation of $500 \mathrm{~m} / \mathrm{L}$. According to WHO (2002) and Allen et al. (2004), Total Heterotrophic Bacteria (THB) in drinking water are not a health concern to the general public but are indications of culturable organisms present. The various tests conducted supported Kowalski's (2003) research which showed that clay filters had an excellent efficiency for removing of turbidity and microbial indicators.

\section{CONCLUSION}

It was concluded that the treatment of the ceramic filter by silver solution improved bacterial removal efficiency by disinfection properties of silver. Furthermore, the model formulation of $\mathrm{C}_{3} 80$ and $\mathrm{C}_{4} 80$ used to stimulate $E$. coli and faecal coliform removal to a reasonable lowest level indicating silver treatments improve ceramic filter performance by a disinfection mechanism. However, impregnating silver with the filters will likely depend on the density of water, the amount of silver applied and the porosity of the filters.

Again, it has been concluded that Akutuase clay together with the rice husks and sawdust that could easily be obtained from the community have been utilised to manufacture clay filters. The following proportion of materials; compositions $\mathrm{C}_{3} 80$ and $\mathrm{C}_{4} 80$ made up of $80 \%$ clay, $15 \%$ rice husks and $5 \%$ sawdust that was fired at 900 and $950^{\circ} \mathrm{C}$ respectively, became successful and suitable for water filtration. However, it was highly successful when the temperature was $950^{\circ} \mathrm{C}$ due to a comparatively the greater quantity of water that $\mathrm{C}_{4} 80$ was able to filter.

Conclusively, filters made from relatively uniform and fine particle size distributions clay samples would likely be efficient with the greater number of smaller pores through higher temperature-firing point and better bacteria removal than the comparatively lesser number of smaller pores through moderately higher temperature-firing point and fairly good bacteria removal.

\section{RECOMMENDATIONS}

Based upon the conclusions, it is recommended that:

- The researchers intend to collaborate with the Community Water and Sanitation Agency (CWSA) to sensitize indigenes of Akutuase about the need to filter the contaminated river in the community before using the water for domestic and other uses and also to transfer the technical know-how to the community.

- As a measure to prevent water-borne diseases in Akuatuase, Non-Governmental Organizations (NGOs) and government and for that matter the District Assemblies should invest in setting up small scale ceramic industry in the community for mass-production of clay filters to serve the rural folks.

- To serve as a source of income in the community, clay winners and rice farmers who normally after harvesting rice burn the husks to pollute the environment could sell the waste products to the proposed small scale ceramic industry for the production of clay filters.

- Further studies should be extended to analyze the removal of other pathogens including viruses and protozoa for different water-quality conditions. Additionally, the long-term field performance of locally produced filters and their effects on human health must be investigated.

\section{REFERENCES}

Allen, M.J., S.C. Edberg and D.J. Reasoner, 2004. Heterotrophic Plate Count Bacteria--What is their Significance in Drinking Water? United States Environmental Protection Agency (USEPA) Paper 93. Office of Water, USA.

Annan, E., 2016. Clay ceramic materials for water filtration: Properties, processing and performance. Unpublished Ph.D. Thesis, submitted to the Department of Material Science and Engineering, African University of Science and Technology (AUST), Abuja, Nigeria. 
Bielefeldt, A.R., K. Kowalski, C. Schilling, S. Schreier, A. Kohler and R.S. Summers, 2010. Removal of virus to protozoan sized particles in point-of-use ceramic water filters. Water Res., 44(5): 1482-1488.

Chung, D.H., J.N. Kinatu, K.O. Nyariki, K.J. Su, K.N. Onura and J.U. Kitheka, 2013. Introducing efficient low cost smoked pots for water purification for developing countries. Hydrol. Current Res., 4(2): 1-5.

Clasen, T.F., J. Brown, S. Collin, O. Suntura and S. Cairncross, 2004. Reducing diarrhea through the use of household-based ceramic water filters: A randomized, controlled trial in rural bolivia. Am. J. Trop. Med. Hyg., 70(6): 651-657

Clasen, T., W.P. Schmidt, T. Rabie, I. Roberts and S. Cairncross, 2007. Interventions to improve water quality for preventing diarrhoea: Systematic review and meta-analysis. BMJ, 334(7597): 782.

Conant, F. and P. Fadem, 2012. Improving Community Health. Community Guide to Environmental Health. Berkeley, California, USA. Retrieved from: www.hesperian.org. Health Guides. (Accessed on: 12/10/18).

Danquah, J.B., 2005. Clay Deposits in Ghana. BiAnnual Journal of the Building and Road, Research Institute, Council for Scientific and Industrial Research (CSIR), Ghana, Vol. 19.

Erhuanga, E., I.B. Kashim and T.L. Akinbogun, 2014. Development of ceramic filters for household water treatment in Nigeria. Art Design Rev., 2(1): 6-10.

Kowalski, K., 2003. Investigation of the turbidity and TOC concentration of the filtrön ceramic filter. School of Civil and Environmental Engineering, University of Colorado, Colorado, USA.
Mintz, E.D., F.M. Reiff and R.V. Tauxe, 1995. Safe water treatment and storage in the home. A practical new strategy to prevent waterborne disease. JAMA, 273: 948-953.

Naddafi, K., A.M. Mahvi, S. Nasseri, M. Mokhtari and H. Zeraati, 2005. Evaluation of the efficiency of clay pots in removal of water impurities. Iran. J. Health Sci. Eng., 2(2): 12-16.

NRC (National Research Council), 1997. Safe Water from Every Tap: Improving Water Service to Small Communities. National Academy Press, Washington, DC, pp: 66.

Rob, D., F. Xanat, P. Melanie and T. Georges, 2003. Point-of-Use Water Treatment Technology Investigations in Nepal. Clean Water for Nepal, Inc., Cambridge, MA 02139.

Sobsey, M.D., 2002. Managing Water in the Home: Accelerated Health Gains from Improved Water Supply. World Health Organization, Geneva, Switzerland.

Speight, C.F. and J. Toki, 1999. Hands in Clay. 4th Edn., McGraw-Hill Co., Inc., New York, U.S.A.

WHO (World Health Organization), 2002. Heterotrophic Plate Count Measurement in Drinking Water Safety Management. Protection of the Human Environment, Water, Sanitation and Health. World Health Organization, Report of an Expert Meeting, Geneva, Switzerland, April 24-25, 2002.

WHO (World Health Organization), 2010. Progress on Sanitation and Drinking Water. WHO Press, World Health Organization, Geneva, Switzerland.

Zereffa, E.A. and T.B. Bekalo, 2017. Clay ceramic filter for water treatment. Mater. Sci. Appl. Chem., 34: 69-74. 